\title{
Running Compression Garments Design Using Biomass Graphene Modified Fiber ${ }^{\star}$
}

\author{
Xiaochen $\mathrm{Li}^{\mathrm{a}}$, Li Liu ${ }^{\mathrm{a}, *}$, Shuangcheng Wang ${ }^{\mathrm{b}}$ \\ ${ }^{a}$ Beijing Institute of Fashion Technology, No. 2 Yinghua Road Chaoyang District, \\ Beijing 100029, China \\ b Jinan Shengquan Group Co. LTD., Jinan, Shandong 250200, China
}

\begin{abstract}
This Paper elaborates the performance of biomass graphene modified fibers and the importance of muscle protection during running. Then, it analyzes the muscle contraction and relaxation during the running process and the human thermal-wet comfort. According to the needs, we conduct the human body partition and enter the design of the compression garments. During the design process, the functionalities of graphene modified fibers and the advantages of seamless knitting are explained. The function and technique are integrated to ensure the scientific and rationality of compression garments design. Finally, the detailed design concept are illustrated.
\end{abstract}

Keywords: Biomass Graphene Modified Fibers; Compression Garments; Running Protection; Thermal-wet Comfort; Seamless Knitting

\section{Introduction}

Graphene is a revolutionary material. It has excellent optical, electrical, and mechanical properties. Graphene has important application prospects in materials science, micro-nano processing, etc. [1]. Biomass graphene manufacturing from biological raw materials adopts "group coordination and assembly" method. This new biomass graphene materials has the functions of far-infrared, long-term antibacterial, anti-static, anti-ultraviolet radiation, constant temperature heat storage and conductive. We modify the fiber to take advantage of the excellent properties of biomass graphene. This smart fiber can effectively enhance the body's comfort experience, and is currently widely introduced to sports, outdoor, underwear, protective gear, home textiles.

The high-performance sport garments design is carried out in this paper. It is based on running compression garments, using biomass graphene-modified fibers as material, and ergonomics as the background.

${ }^{\star}$ Project supported by Beijing Key Laboratory of Clothing Ergonmics and Innovation Functional Design program (KYTG02170202).

* Corresponding author.

Email address: fzyll@bift.edu.cn (Li Liu). 


\section{Muscle Movement Law and Compression Area Division During Running}

In running sports, muscle damage seems to be a topic that can never be avoided. Overtraining and unfamiliar training movements can cause uncomfortable symptoms such as muscle aches, muscle spasms or strains. Most of these symptoms are related to the way of running and the muscle groups that produce running movements [2]. When the muscles are severely damaged, unbearable pain occurs. Therefore, it is particularly important to scientifically and rationally develop and design such compression garments. It helps to relieve lactic acid accumulation, strengthen muscle recovery, and increase muscle strength.

\subsection{Active Muscle Groups During Running Movements}

Dividing the cycle of the upper and lower body movements during running. The movement of the upper limbs is smaller than that of the lower limbs, the cycle of the upper limbs during running is divided into two parts of the front and rear arms swing. The relative amplitude of the lower extremities is relatively large. According to the simple running cycle division, it is divided into three stages: stretching, vacant and landing cushioning [3].

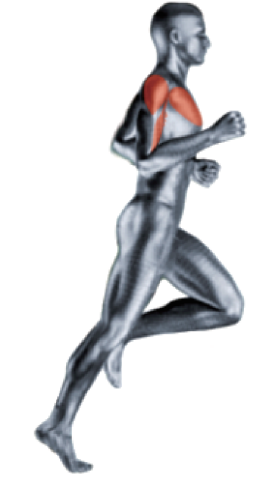

(a) Front arms swing

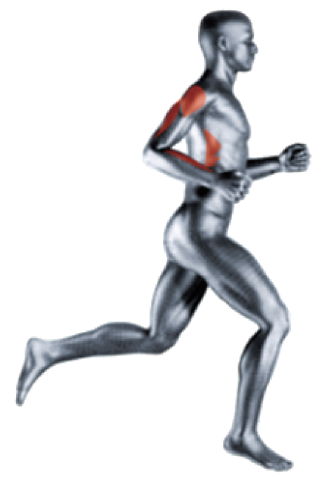

(b) Rear arms swing

Fig. 1: Two stages division of upper limbs running cycle

The table below is the analysis of muscles participating into movements based on the characteristics of running at each stage. The muscles in each stage of the cycle are shown in Fig. 3.

\subsection{Muscle Block Division of Running Movement Function}

The division of blocks is based on the force of muscle groups [8] involved during running (Fig. 3). In addition to the necessary compression protection of the human body, the concept of "gradient compression" is widely proposed and applied. The Australian brand SKINS, 2XU, and the Japanese sports brand CW-X are pioneers of this concept. Drawing on the research results of the above branded products [9-11]. Proceeding from the perspective of human ergonomics and biomechanics, Compression garments place high pressure on the extremities far from the heart to accelerate blood circulation and increase the amount of sports groups oxygen supplied. 


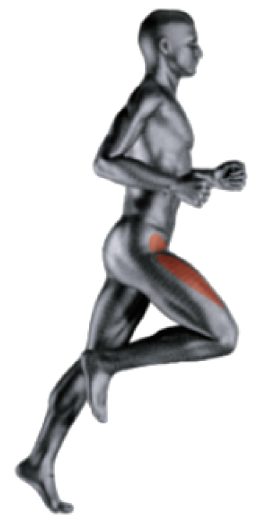

(a) Stretching of lower limps

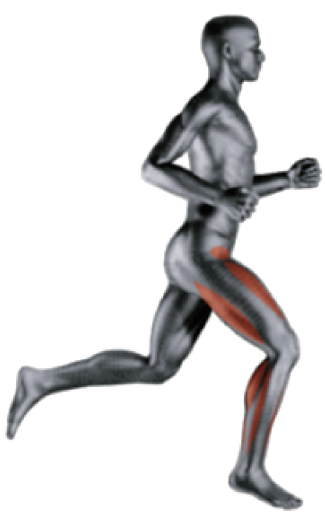

(b) Vacant

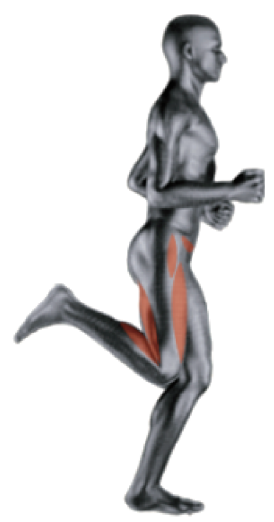

(c) Landing cushioning

Fig. 2: Three stages division of lower limbs running cycle

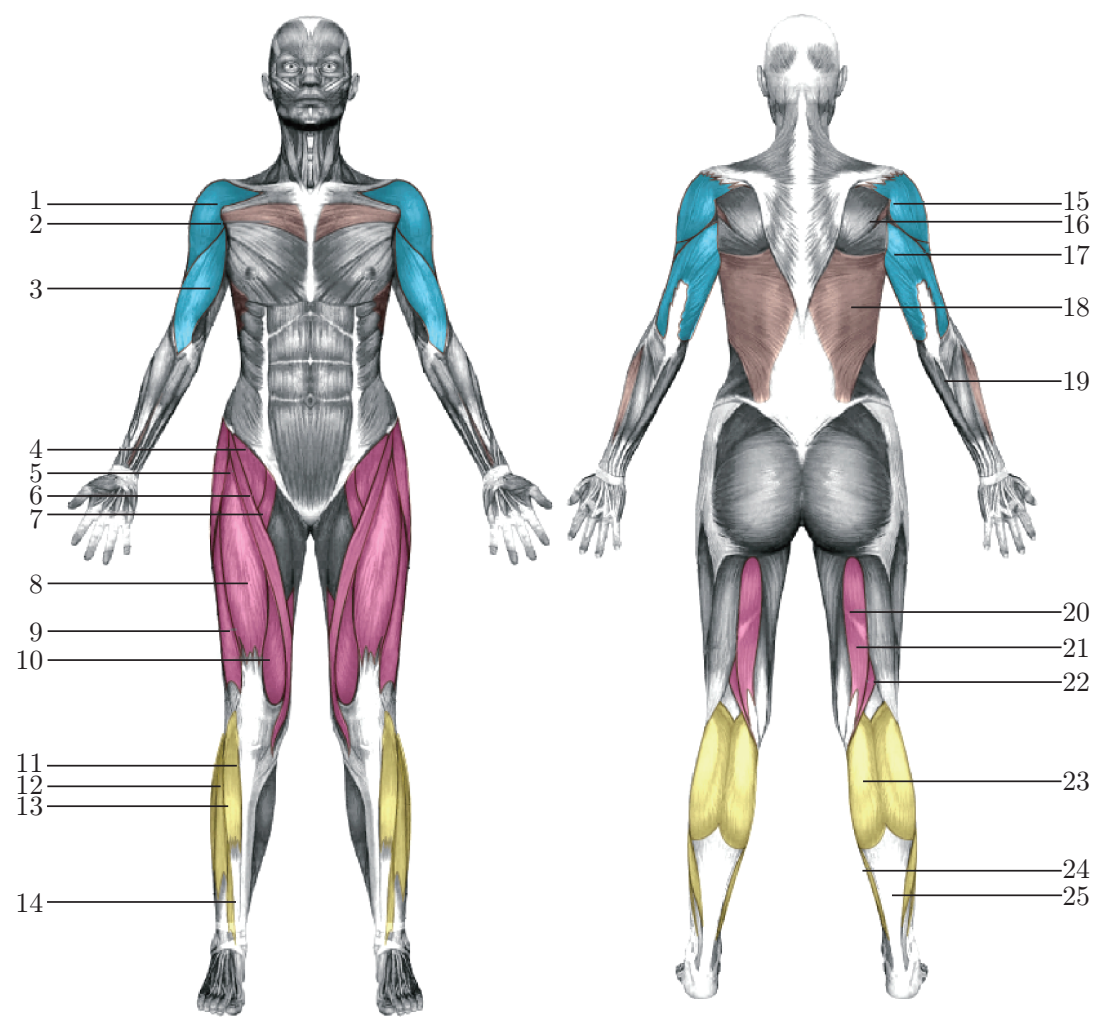

1-Frontal deltoid; 2-Pectoralis major; 3-Biceps brachii; 4-Iliopsoas; 5-Tensor fasciae latae; 6-Sartorius; 7-Pectineal muscle; 8-Rectus femoris; 9-Vastus lateralis muscle; 10 - Medial vastus muscle; 11 - Tibialis anterior muscle; 12 - Gastrocnemius muscle; 13-Peroneus; 14-Extensor pollicis longus; 15-Middle and posterior deltoid; 16-Teres minor; 17-Musculus triceps brachii; 18-Latissimus dorsi; 19-Brachioradialis; 20-Semitendinosus; 21-Biceps femoris muscle; 22-Semimembranosus; 23-Gastrocnemius muscle; 24-Flexor digitorum longus; 25-Musculi soleus

Fig. 3: Muscle block divisions of running movements

In the cooperation and choice of human muscle protection and gradient compression, the red region with the largest force in the figure [12] is the key compression protection zone. The main muscles are iliopsoas, rectus femoris, sartorius, tensor fasciae latae, pectineal muscle, vastus lateralis muscle, and vastus medialis muscle. The yellow area is the second compression area [9], but it is the key gradient compression area. The main muscles are: tendinosus musele, semimembranosus, biceps femoris muscle, sartorius, gracilis and gastrocnemius muscle. The force 
Table 1: Mainly contracting diastolic limb muscles during exercise [7]

\begin{tabular}{|c|c|c|}
\hline \multicolumn{2}{|c|}{ Movement stage } & Muscle \\
\hline Upper limb & Upper arm & $\begin{array}{l}\text { deltoid muscle, biceps brachii muscle, Pectoralis major, coracobrachialis, } \\
\text { brachialis muscle }\end{array}$ \\
\hline & Lower arm & $\begin{array}{l}\text { brachioradialis and pronator teres, musculi flexor earpi radialis, Extensor } \\
\text { carpi radialis muscle }\end{array}$ \\
\hline \multirow[t]{2}{*}{ Lower limb } & Thigh & $\begin{array}{l}\text { iliopsoas, rectus femoris, sartorius of hip flexors, semitendinosus, } \\
\text { semimembranosus, biceps femoris muscle, gluteus maximus }\end{array}$ \\
\hline & Lower leg & $\begin{array}{l}\text { hip flexors, iliopsoas, rectus femoris, sartorius, tibialis anterior, extensor } \\
\text { longus pollicis, lexor digitorum longus, musculi flexor pollicis longus, } \\
\text { peroneus longus of flexor of the foot }\end{array}$ \\
\hline
\end{tabular}

in the blue area is the minimum. When compression garment design, we mainly focus on comfort and guarantee of joint movement [10], and the compression protection is relatively weak. The main muscles are: deltoid muscle, biceps brachii, pectoralis major muscle, coracobrachialis, latissimus dorsi, teres minor and triceps brachii muscle.

In running sports, the fatigue of the upper limbs is much smaller than that of the lower limbs, and the movement of the muscles in the small arms during exercise is not obvious. Therefore, when we have the gradient compression design of upper limb compression garment on the small arm part, its strength is much smaller than that of the calf.

Research results based on muscle function during runningcarry out pressure belt design. The maximum range of fixation and support of the main muscle groups in motion is achieved by wrapping and wrapping (Fig. 4). The belt design increases the lateral strength of the compression garment to ensure stable performance of the compression garment.
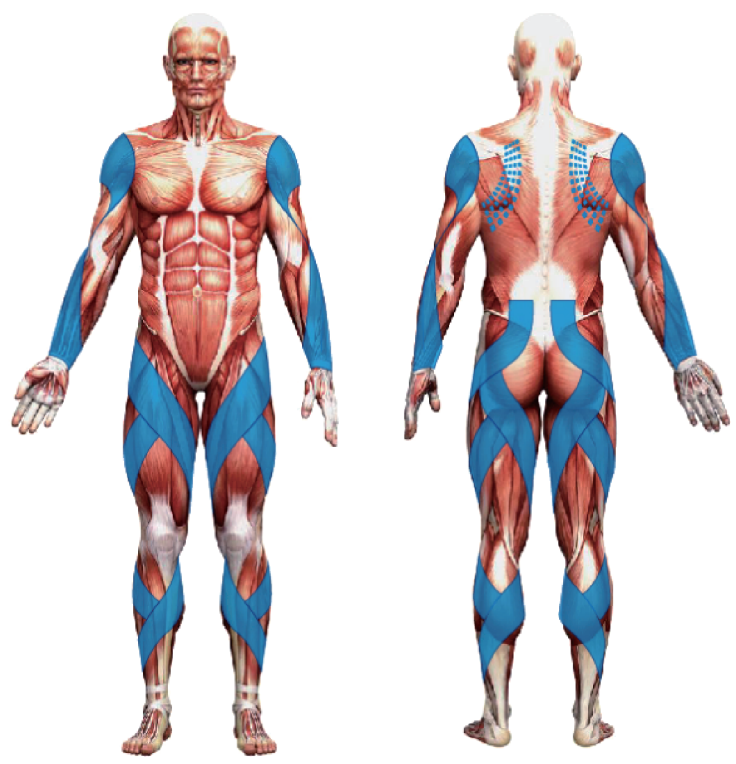

Fig. 4: Running compression suit muscle pressure belt design 


\section{Compressive Clothing Pressure Comfort Study}

Pressure comfort is one of the most important indicators for the comfort assessment of compression garments. High quality compression garments must have good pressure comfortAt the same time, it will increase muscle strength, relieve lactic acid accumulation, and enhance exercise protection. The threshold value of pressure in the literature is mainly determined by the combination of objective test and subjective evaluation. The research results of the dressing pressure comfort of the existing literature are summarized and summarized, and the pressure comfort value of each part of the body is obtained as shown in Fig. 5.

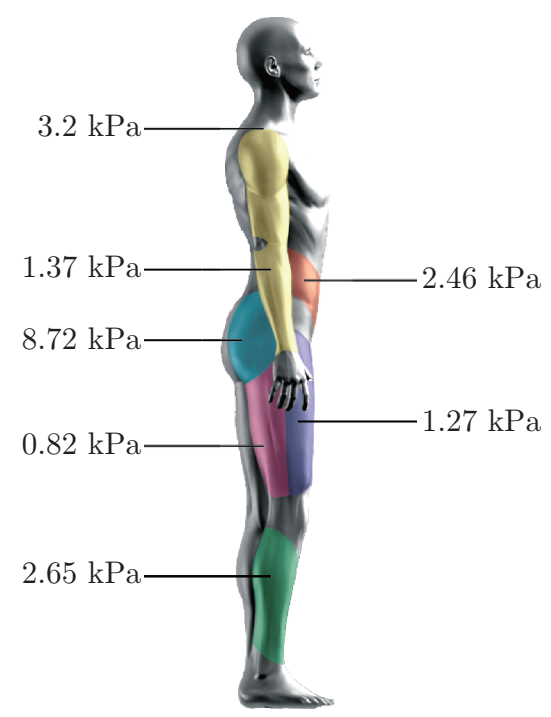

Fig. 5: Pressure comfort variability in all parts of the body [12-17]

\section{Human Body Thermal and Humid Distribution Re- search Design In Running Sports}

During the movement of the human body, the compression garment is worn closest to the body skin, and the compression garment plays a decisive role in the heat dissipation of the human body. Fig. 6 is an infrared thermal image of the human body performing moderate motion in an almost naked natural state. It can be seen that the body's torso is increased in heat relative to the limbs under exercise, and the chest, underarm, and back are the main hot and humid regions. The structural design of the compression garment takes into account these heat transfer and moisture guiding factors.

\section{$5 \quad$ Design of Compression Clothing}

\subsection{The Properties of Graphene Modified Fiber}

Table 2, Table 3, and Table 4 are based on "GB/T 14463-2008 Regenerated Cellulose Fiber" "GB/T 20944.3-2008 Evaluation of Antibacterial Properties of Textiles" "GB/T 30127-2013 Tex- 


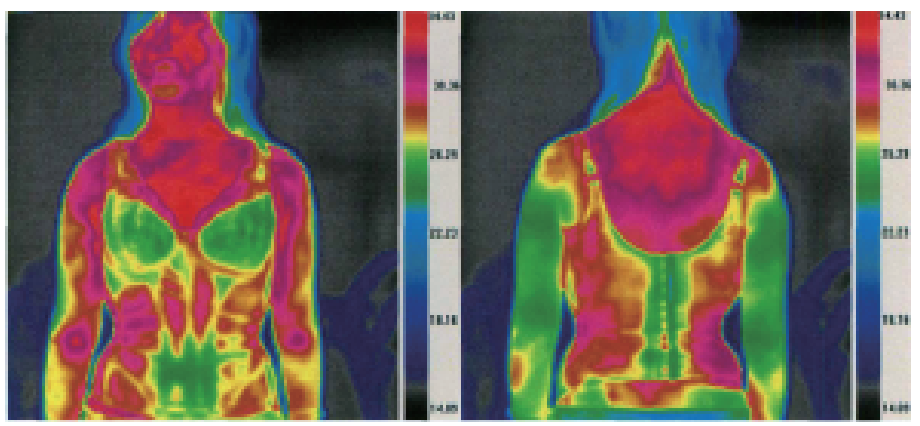

Fig. 6: Infrared thermography of human body in running [18]

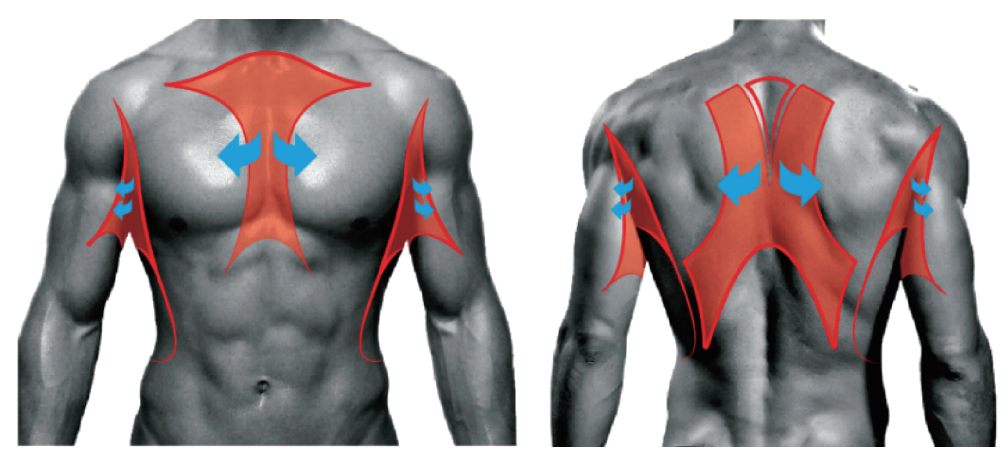

Fig. 7: Thermal and humid area design division

tiles Far Infrared Performance Testing And Evaluation", and they constitute the test results of graphene modified nylon fiber in physical properties, antibacterial and far-infrared projects.

Table 2: Physical property test of bio-based graphene modified nylon fiber filament (1 wt\%)

\begin{tabular}{clcc}
\hline $\begin{array}{c}\text { Serial } \\
\text { number }\end{array}$ & \multicolumn{1}{c}{ Test items } & $\begin{array}{c}\text { Standard value } \\
\text { (first grade) }\end{array}$ & Result \\
\hline 1 & Breaking tenacity (cN/dtex) & $\geq 3.20$ & 4.52 \\
2 & Breaking strength coefficient of variation (\%) & $\leq 10.00$ & 3.67 \\
3 & Elongation at break (\%) & $/$ & 26.97 \\
4 & Breaking elongation coefficient of variation (\%) & $\leq 12.00$ & 5.68 \\
5 & Crimp retraction (\%) & $\geq 10.0$ & 32.9 \\
6 & Curling stability (\%) & $/$ & 69.3 \\
7 & Curl elasticity (response) rate (\%) & $/$ & 80.2 \\
8 & Curl (elongation) rate (\%) & $\leq 1.80$ & 61.8 \\
9 & Linear density (dtex) & \pm 3.5 & 77.8 \\
10 & Linear density coefficient of variation CV (\%) & 0.17 \\
11 & Linear density deviation rate (\%) & -2.2 \\
\hline
\end{tabular}

Nylon is the main fiber material for weaving compression garments. According to scientific experiments, the modified nylon fiber containing graphene has better mechanical properties than conventional nylon fiber. And it has excellent antibacterial capabilities. In addition, its powerful 
Table 3: Anti-bacteria test items of bio-based graphene modified nylon fiber filament

\begin{tabular}{cccc}
\hline & $\begin{array}{c}\text { Colibacillus } \\
\text { antibacterial rate }\end{array}$ & $\begin{array}{c}\text { staphylococcus aureus } \\
\text { antibacterial rate }\end{array}$ & $\begin{array}{c}\text { Candida albicans } \\
\text { antibacterial rate }\end{array}$ \\
\hline Before washing & 98 & $>99$ & 98 \\
Washing for 50 times & 98 & $>99$ & 98 \\
\hline
\end{tabular}

Table 4: Far infrared test items of bio-based graphene modified nylon fiber (1 wt\%)

\begin{tabular}{ccccc}
\hline Serial number & Test item & unit & standard parameter & Test index \\
\hline 1 & Far infrared emitting rate & $\%$ & $\geq 0.8$ & 0.88 \\
2 & Far infrared irradiation and temperature rise & ${ }^{\circ} \mathrm{C} / 30 \mathrm{~s}$ & $\geq 1.4$ & 2.3 \\
\hline
\end{tabular}
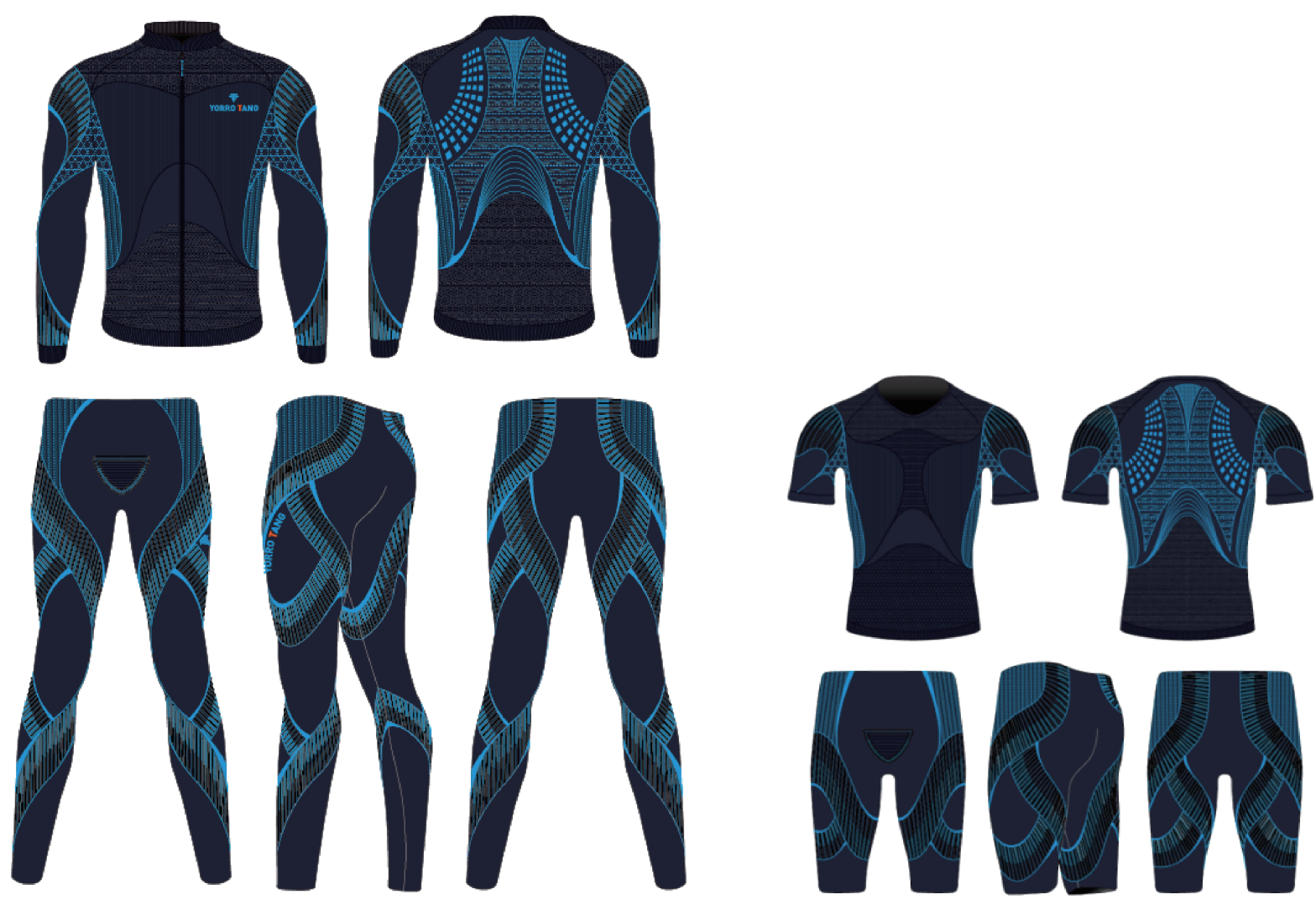

Fig. 8: Men seamless knitting compression garment design

low-temperature far-infrared performance can promote blood circulation and enhance body functions. Choosing a compression garment of biomass graphene modified fiber woven can maximize the performance of the biomass graphene modified fiber. As a result, the functional properties of the compression garment are substantially improved [19-20]. This optimization of the combination of biomass graphene modified fibers and modern technologies. Promote the development of running compression garments to the most robust protection and the highest efficiency. which is the focus of research and design. 

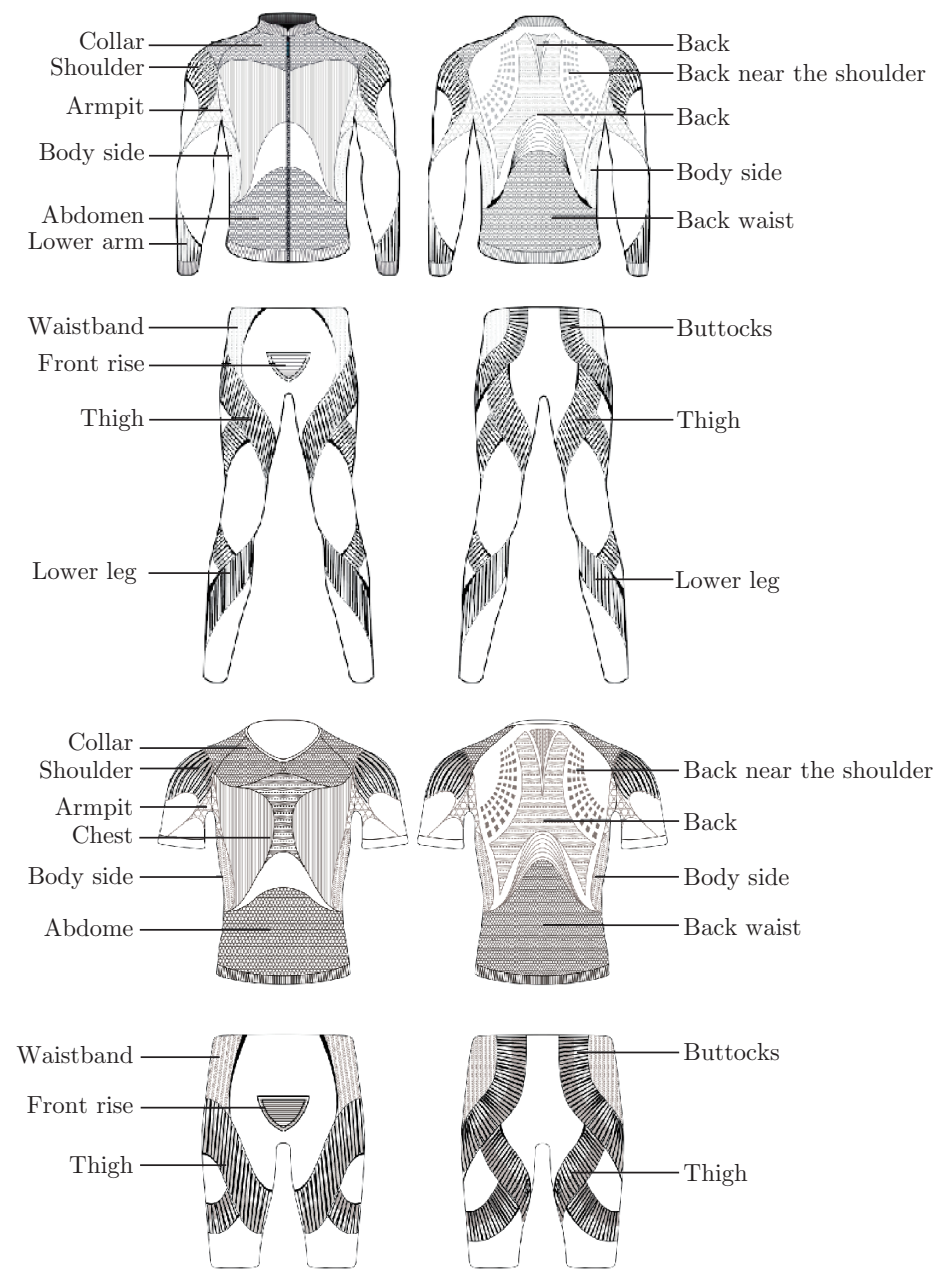

Fig. 9: Note of design picture

\subsection{Seamless Knitting Technique}

Seamless knitting garments have very few seams on the body structure. It has the features of excellent elasticity, body-fitting and skin-friendliness [21-23]. And proceeding from the human body's natural curve and physiological function. The article use modern computer technology to conduct change design, so as to make the compression garment production more ergonomic. Compression garments with seamless knitting technology provide comprehensive functionality that adjusts pressure comfort and thermal and humid comfort as a whole.

\subsection{Functional Design Illustration of All Parts of Compression Wear}

In accordance with the two major performances of compression protection to promote performance improvement and thermal and wet comfort. The main functions of compression garments are divided into two categories. The areas of compression protection (Table 5) include: shoulder, abdome, back waist, back near the shoulder, thigh, buttocks; the lower arm and lower leg area are the gradient compression area in the compression protection; the front rise and knee are the focus protective area.The hot and humid areas (Table 6) include: collar, body side, back waist, chest, armpit and back. 
Table 5: Design illustration of compression protection area

\begin{tabular}{|c|c|c|c|}
\hline position & pattern & Design method & Design principle \\
\hline Shoulder & & $\begin{array}{l}\text { The stripe webbing de- } \\
\text { sign has greater lateral } \\
\text { force than longitudinal } \\
\text { force. }\end{array}$ & $\begin{array}{l}\text { (1) Apply pressure on the deltoid muscles to reduce the accu- } \\
\text { mulation of lactic acid during swings. } \\
\text { (2) Here is the area where the raglan sleeves and the body } \\
\text { part are sewn, and it is the area where the human body can } \\
\text { have wrinkle easily when wearing clothes. The design ensures } \\
\text { the wear is smooth. } \\
\text { (3) The knitting method is tight and powerful, and the stabil- } \\
\text { ity is high. That can prevent deformation of the compression } \\
\text { garment caused by excessive stretching. }\end{array}$ \\
\hline Body side & & $\begin{array}{l}\text { Abdominal stability } \\
\text { design extends to the } \\
\text { abdomen }\end{array}$ & $\begin{array}{l}\text { (1) Reduce the vibration of abdominal muscles during run- } \\
\text { ning. } \\
\text { (2) When the movement speed is fast, the air rapidly passes } \\
\text { over the abdomen. The air pressure in front of the abdomen } \\
\text { is greater than that behind the body. The air diverts from the } \\
\text { abdomen to both sides, resulting in rapid air flow in the ab- } \\
\text { domen and the body side. Therefore, the design is extended to } \\
\text { the abdomen to ensure normal body functioning. } \\
\text { (3) Prevent the slide of the jacket caused by the movement. }\end{array}$ \\
\hline $\begin{array}{l}\text { Back near } \\
\text { the shoul- } \\
\text { der }\end{array}$ & & $\begin{array}{l}\text { Extended wave point } \\
\text { design }\end{array}$ & $\begin{array}{l}\text { (1) Supports back muscles and optimizes human running pos- } \\
\text { ture. } \\
\text { (2) Satisfy the body bending and stretching. }\end{array}$ \\
\hline Thigh & & $\begin{array}{l}\text { Compression protec- } \\
\text { tion design and the } \\
\text { shape extends along } \\
\text { human muscle curve }\end{array}$ & $\begin{array}{l}\text { (1) Strong fabric tissue pressure can reduce the vibration of } \\
\text { soft tissues, muscles and promote blood circulation. } \\
\text { (2) Special shape design can constitute strong support for } \\
\text { thigh muscles, reduce muscle damage. }\end{array}$ \\
\hline Buttocks & & $\begin{array}{l}\text { Muscle lifting band de- } \\
\text { sign }\end{array}$ & $\begin{array}{l}\text { In addition to the muscles of the buttocks, it is also a fat } \\
\text { accumulation place. Here the design guarantees the beauty } \\
\text { and improves the proportion of the human body. }\end{array}$ \\
\hline $\begin{array}{l}\text { Lower } \\
\text { arm }\end{array}$ & & $\begin{array}{l}\text { Elbow protection and } \\
\text { gradient pressure ring } \\
\text { design }\end{array}$ & $\begin{array}{l}\text { (1) In the process of running, the arm muscle forces are small } \\
\text { and it is relatively far away from the heart. Gradient com- } \\
\text { pression design is mainly used [9-10]. } \\
\text { (2) Conduct silicon fitting inside the arm to enhance the tight- } \\
\text { ness of the arm pressure. According to the structure of the } \\
\text { human body, conduct ring-shaped design with different ring } \\
\text { pressure values. So that the local design increases the scien- } \\
\text { tificity and comfort. }\end{array}$ \\
\hline Lower leg & & $\begin{array}{l}\text { Calf compression and } \\
\text { gradient pressure ring } \\
\text { design }\end{array}$ & $\begin{array}{l}\text { (1) The calf muscle needs sport power generation.If running } \\
\text { time is too long, the resulting fatigue of calf muscles with the } \\
\text { increase of exercise intensity. Therefore we should conduct a } \\
\text { certain amount of stable compression towards the legs. } \\
\text { (2) Like the arm, due to the distance from the heart, in order } \\
\text { to promote blood circulation, the leg has the need for gradient } \\
\text { pressure design [9-10]. }\end{array}$ \\
\hline Front rise & 害要政 & $\begin{array}{l}\text { Invisible weave protec- } \\
\text { tion design }\end{array}$ & $\begin{array}{l}\text { (1) Because of the different body structure of men and women, } \\
\text { its design is limited to men. } \\
\text { (2) Ensure a certain tensile elasticity, at the same time the } \\
\text { thickness on this part is slightly larger than that on other } \\
\text { parts. }\end{array}$ \\
\hline
\end{tabular}


Table 6: Thermal and humid area design illustration

\begin{tabular}{|c|c|c|c|}
\hline position & pattern & Design method & Design principle \\
\hline Collar & & $\begin{array}{l}\text { Auxiliary perspira- } \\
\text { tion design }\end{array}$ & $\begin{array}{l}\text { The clavicle fossa of the collar and the back waist } \\
\text { are areas where sweat easily accumulates. Therefore, } \\
\text { we make the structural design of the auxiliary sweat } \\
\text { evaporation. The purpose is to keep the body dry. }\end{array}$ \\
\hline $\begin{array}{l}\text { Chest, } \\
\text { Armpit }\end{array}$ & |i: & $\begin{array}{l}\text { Radiant and mois- } \\
\text { ture guide design } \\
\text { for arc area division } \\
\text { in accordance with } \\
\text { the arc of the pec- } \\
\text { toralis major and } \\
\text { axillae fossa }\end{array}$ & $\begin{array}{l}\text { (1) From the infrared thermal image of the human } \\
\text { body during running, it can be seen that these two } \\
\text { regions have very high temperature in the early stage } \\
\text { of exercise. They are also the main physiological } \\
\text { sweat areas. The heat dissipation and moisture con- } \\
\text { trol system design accelerates the evaporation of } \\
\text { sweat and heat. } \\
\text { (2) Make auxiliary segmentation areas on the chest } \\
\text { and armpits. increase the functional area and meet } \\
\text { the human perspiration and humid control require- } \\
\text { ments. } \\
\text { (3) After a certain period of time, the heat dis- } \\
\text { sipation and humid control system begins to have } \\
\text { thermal insulation and guarantees human physical } \\
\text { health. }\end{array}$ \\
\hline Back & $\int$ & $\begin{array}{l}\text { Spinal support pro- } \\
\text { tection and wet dis- } \\
\text { sipation insulation } \\
\text { design }\end{array}$ & $\begin{array}{l}\text { (1) The back is the main cooling and moisturizing } \\
\text { part. Its timing insulation effect is delayed because } \\
\text { it is a sheltered site during running. } \\
\text { (2) The middle spine support design can provide } \\
\text { strong protection to the spine. }\end{array}$ \\
\hline
\end{tabular}

\section{Conclusion}

The paper summarizes the excellent performance of biomass graphene modified fiber and analyzes the muscle force while running. Dividing the heat dissipation and humid control area in accordance with the thermal and humid comfort of human body. Based on the above research result, designs the running compression clothing for men and women while illustrating in detail the design of all parts. In the future, pressure comfort tests and improvement for greater quality compression clothing constitutes as a research priority.

Taking advantage of biomass graphene modified fibers, we've developed this running compression garment. This new type of functional running compression garment is supported by human ergonomics, supplemented by biomass graphene modified fibers, coordinates with strict and efficient modern production technology. So as to fully exert the functions of antibacterial and promoting blood circulation. satisfying the needs of contemporary people for compression clothing in smart clothing. Compression garments application of biomass modified graphene fibers is a 
major technological innovation. It can promote the biomass graphene modified fiber more intelligent and make the design of compression garments more user-friendly. Promoting compression clothing for the future development to have constant technology innovating. Follow closely as the paces of technological development meets the market requirements in a far superior way.

\section{Acknowledgement}

The authors wish to acknowledge the Beijing Key Laboratory of Clothing Ergonmics and Innovation Functional Design program (KYTG02170202).

\section{References}

[1] Xu XJ, Qin JG, Li Z. Progress on Graphene Research [J]. Progress in chemistry, 2009, 21(12): 2559-2567.

[2] John A. Sports Medicine and Science Handbook-Running [M]. Beijing: People's Sports Publishing House, 2002: 92-95.

[3] Xu L, Guo Q, Chen HY. Optimal solution and analysis of redundant muscle strength of lower limbs in running [J]. Journal of Beijing Institute of Technology, 2004, 24(10): 869-873.

[4] Wang S. Research on common mistakes and training methods of sprint arm swing technology [J]. Theories of sport training, 2015, 5(35): 45-47.

[5] Jing JH, Qiu XH, Qin YX. Analysis and Research on Swing Arm Technique and Sprint Performance [J]. Journal of Hubei Sports Science, 2013, 32(10): 864-867.

[6] Philip S. Running exercise (complete diagram of muscle training) [M]. Beijing: Posts and Telecom Press, 2015: 22-23.

[7] Cui XC, Mao XH. On the Re-division of Period of Running Cycle [J]. China Sport Science and Technology, 2003, 39(2): 49-51.

[8] Zhao XX. Protection research and product development of lower limb musculoskeletal system during marathon running $[D]$. Shanghai: Shanghai university of engineering science and technology, 2015: 23-24.

[9] Duffy BT, Duffy SK. Compression garments and a method of manufacture: World Intellectual Property Organization, WO2006032096 [P]. 2006: 03-30.

[10] Mclaren J, Herrod A, Barton P.Compression garments and a method of manufacture: World intellectual property organization, WO2010132950 [P]. 2010: 11-25.

[11] J.Lemmens. Industr.Text [M]. Belge, 1966, 8: 71.

[12] Verillo R T.Cutaneous sensations [ C] B Scharf (Ed). Experimental Sensory Psychology. Glenview: Scott Foresman, 1975: 1-10.

[13] Makabe H. A study of clothing pressure developed by the girdle [J]. Jpn Res Asn Tex End Uses, 1991, 32(9): 424-438.

[14] Makabe H, Momota H, Mitsuno T, eta1. A study of apparel pressure developed by the brassiere [J]. J Jpn Res Assn Text End Uses, 1991, 32(9): 416-423.

[15] Makabe H, Momota H, Mitsuno T, eta1.Effectof covered area at the waist on clothing pressure [J]. Seni Gakkaishi, 1993, 49: 513-521.

[16] Momota, Hiroko, et al.A study of clothing pressure caused by Japanese men's socks [J]. Jpn. Res.Assn. Text. End-Uses, 1993, 34(4): 175-186. 
[17] Ito, N., et al. The relation among the biaxial extension properties of girdle cloths and wearing comfort and clothing pressure of girdles [J]. Journal of the Japan Research Association for Textile End-uses, 1995, 36(1): 102-108.

[18] X-technology Swiss Co.Ltd. Compression clothing: China, CN102238880A [P]. 2011-11-09.

[19] Feng SS. Thermal and humid comfort study and sample dress development of fitted women running clothes [D]. Beijing: Beijing Institute Of Fashion Technology, 2014: 5-27.

[20] Jin X, Zhang WQ. Biomass graphene inner warm knitting fabric production practice [J]. Textile industry, 2017(9): 16-18.

[21] Yu RR, Tian MW, Qu LJ. Graphene composite fiber and functional finishing study progress of textiles [J]. Journal of Chengdu Textile College, 2017, 34(3): 180-184.

[22] Zhou SM. PPT new fiber seamless knitting clothing design, Technique and performance study [D]. Shanghai: Donghua University, 2010: 9-13.

[23] Li XQ, Zhao YX. Research progress on dimensional stability of seamless knitted garments [J]. Progress in textile, 2017(4): 1-5.

[24] Chen LY, Song GL. The development of seamless knitting technology [J]. Knitting industry, 2007(9): 70-71. 